\title{
Effect of Different Organic Manures and PGPR Consortium on Growth and Yield of Bottle Gourd (Lagenaria siceraria Mol. Standl.) CV. Anand Bottle Gourd-1
}

\author{
S. R. Nadoda*, A.V. Kotecha, K.S. Vaghela, J.M. Aal \\ Department of Horticulture, B. A. College of Agriculture, Anand Agricultural University, \\ Anand, Gujarat, India \\ *Corresponding author
}

\section{A B S T R A C T}

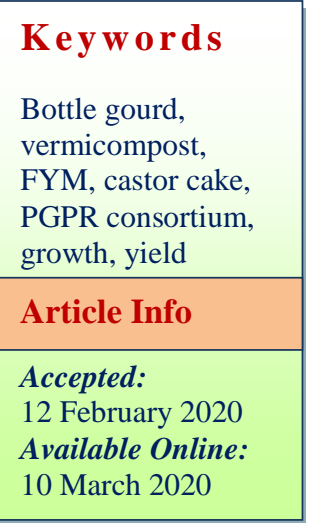

The present investigation was carried out on "Effect of different organic manures and PGPR consortium on growth and yield of bottle gourd (Lagenaria siceraria MOL. STANDL.) cv. ABG-1" at Horticultural Research Farm, Department of Horticulture, B. A. College of Agriculture, Anand Agricultural University, Anand, Gujarat during summer2018. The experiment was laid out in Randomized Block Design with factorial concept (FRBD) replicated thrice with six level of organic manures application and two level of PGPR consortium of total 12 combination. The control [75:50:50 NPK kg/ha + FYM 15 t/ha (RDF)] treatment was taken separately means without combination under experimentation. The experimental result revealed that growth and flowering parameters of bottle gourd viz., number of branches/plant (14.38), number of female flowers/plant (3.16), girth of fruit $(23.85 \mathrm{~cm})$, length of fruit $(30.93 \mathrm{~cm})$ and yield parameters viz., number of fruit/plant $(8.78)$, average fruit weight $(637.79 \mathrm{~g})$, yield per plant $(5.59 \mathrm{~kg})$ and yield $(27.84 \mathrm{t} / \mathrm{ha})$ were found superior with the treatment of $\mathrm{M}_{1}(100 \% \mathrm{RDN}$ from vermicompost) and it was remained at par with the treatment $\mathrm{M}_{5}(100 \% \mathrm{RDN}$ from castor cake) and $\mathrm{M}_{3}(100 \%$ RDN from FYM). PGPR consortium (11/ha) showed the best result to growth and flowering parameters viz., minimum days taken for germination (7.60), maximum number of branches/plant (13.95), number of female flowers/plant (3.01), girth of fruit $(23.06 \mathrm{~cm})$, length of fruit $(29.74 \mathrm{~cm})$ and yield parameters viz., maximum number of fruit/plant (8.40), average fruit weight $(609.38 \mathrm{~g})$, yield per plant $(5.14 \mathrm{~kg})$ and yield (25.73 t/ha) under experimentation.

\section{Introduction}

Bottle gourd (Lagenaria siceraria Mol. Standl.) belongs to the family cucurbitaceae with chromosome number of $2 n=22$. Its native is tropical Africa and Asia. It is commonly known as white-flowered gourd, Lauki, Kaddu and Ghiya. In Gujarat, it is known as Dudhi. In India it is cultivated in about 155 thousand ha area with production of 2573 thousand MT (Anon., 2016-2017). From nutritional point of view, bottle gourd can be considered as nutrition rich fruit vegetable.

It contains considerable amount of water (96.1 g), carbohydrates $(2.5 \mathrm{~g})$, protein $(0.2$ $\mathrm{g})$, fat $(0.1 \mathrm{~g})$, minerals $(0.5 \mathrm{~g})$, fiber $(0.6 \mathrm{~g})$, riboflavin $(0.023 \mathrm{mg})$, vitamin $\mathrm{A}(10 \mathrm{IU})$, vitamin $\mathrm{C}(11 \mathrm{mg})$, calcium $(16 \mathrm{mg})$, iron $(0.4$ $\mathrm{mg}$ ), phosphorus (14 mg) and energy (12 K 
cal) per $100 \mathrm{~g}$ of edible fruit (Gopalan et. al. 1982). Organic manures like vermicompost, FYM and castor cake etc. supply important plant elements both macro and micro. Apart from supplying plant nutrients they favour aggregation of fine soil particles, there by promoting good soil structure and it is also essential for healthy development of soil microorganisms which further carry out biochemical transformation play active role in decomposing organic matter and help in releasing the essential plant nutrients.

PGPR consortium is bio-NPK liquid biofertilizers which contains living organisms when applied to the soil, colonize the rhizosphere or interior of the plant and promote growth by increasing the supply or availability of primary nutrients to the plant. It is an important component of plant nutrient management for sustainable agriculture. BioNPK consortium contain five strains of agriculturally beneficial microorganism (two Nitrogen fixer, two Phosphate solubilizers and one potash mobilizer) is the one time solution for all the macronutrient $(\mathrm{N}, \mathrm{P}, \mathrm{K})$ requirement of crops. Use of Bio-NPK consortium @1 litre/ha can save $25 \% \mathrm{~N}, \mathrm{P}$ and $\mathrm{K}$ chemical fertilizer with increase in yield with reduction of soil, water and air pollution.

The use of high yielding crop varieties with application of heavy doses of chemical fertilizers without organic manures and biofertilizers causes deterioration of soil health in terms of physical and chemical properties of soil, declining of soil microbial activities, reduction in soil humus, increased pollution of soil, water and air. Hence, Nitrogen management through use of organic manures and biofertilizer replacing of present dose of chemical fertilizers of bottle gourd is not worked out so an experiment on "Effect of different organic manures and PGPR consortium on quality of bottle gourd cv. ABG-1" studied.

\section{Materials and Methods}

The experiment was conducted at Horticultural Research Farm, Department of Horticulture, B. A. College of Agriculture, Anand Agricultural University, Anand, Gujarat. The effect of different organic manures and PGPR consortium on growth and yield of bottle gourd studied. The experiment was laid out in Randomized Block Design with factorial concept (FRBD) replicated thrice with six level of organic manures application and two level of PGPR without and dose of 1 l/ha of total 12 combination. The control [75:50:50 NPK $\mathrm{kg} / \mathrm{ha}+\mathrm{FYM} 15 \mathrm{t} / \mathrm{ha}$ (RDF)] treatment was taken separately means without combination under experimentation.

Treatment details given in table no. 1 and treatment combination are given in table no. 2. The bottle gourd cv. Anand Bottle Gourd-1 was sown on $16^{\text {th }}$ February, 2018 at a spacing of $2.0 \mathrm{~m} \times 1.0 \mathrm{~m}$. The gross plot size is $8.0 \mathrm{~m}$ $\mathrm{x} 6.0 \mathrm{~m}$ and net plot size is $4.0 \mathrm{~m} \mathrm{x} 4.0 \mathrm{~m}$. The soil of the experimental site was sandy loam, locally known as "Goradu" with the $\mathrm{pH}$ of soil is 7.06, $0.26 \%$ of organic carbon was determined by walkley and black method, $162.13 \mathrm{~kg} / \mathrm{ha}$ of available nitrogen was determined by kjeldahl digestion method, $30.92 \mathrm{~kg} / \mathrm{ha}$ of available phosphorus was estimated by Olson's extraction method, $176.78 \mathrm{~kg} / \mathrm{ha}$ of available potassium was determined by flame photometric method.

This type of soil is responds well to irrigation and manuring so it is suitable for bottle gourd cultivation. In this experiment three source of organic manurs used viz., vermicompost, FYM, castor cake. Vermicompost having 1.8 $\% \mathrm{~N}, \mathrm{FYM} 0.5 \% \mathrm{~N}$ and castor cake $3.5 \% \mathrm{~N}$. For $100 \%$ of nitrogen dose used quantity of vermicompost 4.16 t/ha, FYM 15 t/ha and castor cake 2.14 t/ha. For $75 \%$ of nitrogen dose used quantity of vermicompost $3.12 \mathrm{t} / \mathrm{ha}$, 
FYM $11.25 \mathrm{t} / \mathrm{ha}$ and castor cake $1.61 \mathrm{t} / \mathrm{ha}$. PGPR consortium used 1 l/ha. These fertilizers were applied in a single dose at the time of sowing as per treatment plan and application of $50 \%$ recommended dose of $\mathrm{N}$ and full dose of $\mathrm{P}$ and $\mathrm{K}$ given as a basal dose and remaining $50 \%$ of $\mathrm{N}$ was applied 30 days after sowing in control. Weeding and plant protection measure were followed as and when needed. The data were statistically analyzed by the method suggested by Panse and Sukhatme (1967).

\section{Results and Discussion}

\section{Growth and flowering parameters}

The results obtained from experiment are presented in relevant Tables 3.

\section{Effect of organic manures}

The experimental result revealed that growth and flowering parameters of bottle gourd viz., number of branches/plant (14.38), number of female flowers/plant (3.16), girth of fruit $(23.85 \mathrm{~cm})$ and length of fruit $(30.93 \mathrm{~cm})$ were found superior with the treatment of $\mathrm{M}_{1}$ (100\% RDN from vermicompost) and it was remained at par with the treatment $\mathrm{M}_{5}(100 \%$ $\mathrm{RDN}$ from castor cake) and $\mathrm{M}_{3}(100 \% \mathrm{RDN}$ from FYM).

While, days taken for germination, number of male flowers/plant and sex ratio were found non-significant. Application of vermicompost might be due to better not only provided plant nutrient but also improve the physical condition of soil in respect of granulation, friability porosity which in term provided a balance nutritional environment favorable both soil rhizosphere and in plant system Reddy et al., (1998). The results were also in accordance with the findings of Das et al., (2015) and Nagar et al., (2017) in bottle gourd.

\section{Effect of PGPR consortium}

Growth and flowering parameters viz., minimum days taken for germination (7.60), maximum number of branches/plant (13.95), number of female flowers/plant (3.01), girth of fruit $(23.06 \mathrm{~cm})$ and length of fruit $(29.74$ $\mathrm{cm})$ were found superior with the application of $\mathrm{P}_{2}$ (With PGPR consortium 1 1/ha). While, number of male flowers/plant and sex ratio were found non-significant. The early germination could be due to the ability of Azospirillum to produce some growth promoting substances like auxins which might have led to enhance the physiological process in seeds, increased uptake of the nutrient and moisture (Kloepper, 2003). The colonization of this bacterium reduced the incidence of seed mycoflora which indirectly enhanced seed germination. PGPR consortium is effective in nitrogen fixation and processing genetic information for cube ring pathogens of crops plants, synthesis of plant growth promoting hormones and proteins, enzymes and other factor that improve uptake of essential nutrients by plants utilized in farming this was also confirmed by Pandey and Kumar (1989). The results were also in accordance with the findings of Kumar et al., (2012) in bitter gourd, Asha et al., (2018) in ridge gourd, Das et al., (2015) and Patel et al., (2018) in bottle gourd.

\section{Yield and its attributing parameters}

The results obtained from experiment are presented in relevant Tables 4 .

\section{Effect of organic manures}

Yield and yield attributing parameters viz., number of fruit/plant (8.78), average fruit weight $(637.79 \mathrm{~g})$, yield per plant $(5.59 \mathrm{~kg})$ and yield (27.84 t/ha) were found superior with the treatment of M1 (100\% RDN from vermicompost) and it was remained at par 
with the treatment M5 (100\% RDN from castor cake) and M3 (100\% RDN from FYM). The beneficially effect of vermicompost on yield and yield attributing parameters might be due to enhanced supply of micro and macro- nutrients during entire growing season. Vermicompost along with nutrients from soil particularly at later stage of crop growth might have increases the rate of photosynthesis with further increased vegetative growth and provided more site for translocation of photosynthesizes with ultimately increased the yield. The results were also in accordance with the findings of Nagar et al., (2017), Singh et al., (2012) and Das et al., (2015) in bottle gourd.

Table.1 Details of various treatments

\begin{tabular}{|c|c|c|}
\hline Sr. No. & Treatments & Symbol \\
\hline \multicolumn{3}{|c|}{ Factor A : Organic manures (M) } \\
\hline 1. & $100 \% \mathrm{RDN}$ from vermicompost (4.16 t/ha) & $\mathrm{M}_{1}$ \\
\hline 2. & 75\% RDN from vermicompost (3.12 t/ha) & $\mathrm{M}_{2}$ \\
\hline 3. & $100 \%$ RDN from FYM (15 t/ha) & $\mathrm{M}_{3}$ \\
\hline 4. & $75 \%$ RDN from FYM (11.25 t/ha) & $\mathrm{M}_{4}$ \\
\hline 5. & $100 \%$ RDN from castor cake (2.14 t/ha) & $\mathrm{M}_{5}$ \\
\hline 6. & $75 \%$ RDN from castor cake (1.61 t/ha) & $\mathrm{M}_{6}$ \\
\hline \multicolumn{3}{|c|}{ Factor $B$ : PGPR consortium (P) } \\
\hline 1. & Without PGPR consortium & $\mathrm{P}_{1}$ \\
\hline 2. & With PGPR consortium (1 lit/ha) & $\mathrm{P}_{2}$ \\
\hline
\end{tabular}

Table.2 Treatment combinations

\begin{tabular}{|c|c|c|}
\hline Sr No. & Treatment combination & Notation \\
\hline 1. & $100 \%$ RDN from vermicompost & $\mathrm{M}_{1} \mathrm{P}_{1}$ \\
\hline 2. & $100 \%$ RDN from vermicompost + PGPR consortium (1 1/ha) & $\mathrm{M}_{1} \mathrm{P}_{2}$ \\
\hline 3. & $75 \%$ RDN from vermicompost & $\mathrm{M}_{2} \mathrm{P}_{1}$ \\
\hline 4. & 75\% RDN from vermicompost + PGPR consortium (1 1/ha) & $\mathrm{M}_{2} \mathrm{P}_{2}$ \\
\hline 5. & $100 \%$ RDN from FYM & $\mathrm{M}_{3} \mathrm{P}_{1}$ \\
\hline 6. & 100\% RDN from FYM + PGPR consortium (1 1/ha) & $\mathrm{M}_{3} \mathrm{P}_{2}$ \\
\hline 7. & $75 \%$ RDN from FYM & $\mathrm{M}_{4} \mathrm{P}_{1}$ \\
\hline 8. & 75\% RDN from FYM + PGPR consortium (1 1/ha) & $\mathrm{M}_{4} \mathrm{P}_{2}$ \\
\hline 9. & $100 \%$ RDN from castor cake & $\mathrm{M}_{5} \mathrm{P}_{1}$ \\
\hline 10. & $100 \%$ RDN from castor cake + PGPR consortium (1 1/ha) & $\mathrm{M}_{5} \mathrm{P}_{2}$ \\
\hline 11. & 75\% RDN from castor cake & $\mathrm{M}_{6} \mathrm{P}_{1}$ \\
\hline 12. & 75\% RDN from castor cake + PGPR consortium (1 1/ha) & $\mathrm{M}_{6} \mathrm{P}_{2}$ \\
\hline 13. & Control 75:50:50 NPK kg/ha + FYM 15 t/ha (RDF) & $\mathrm{M}_{0} \mathrm{P}_{0}$ \\
\hline
\end{tabular}

Note : Common dose of FYM 15 t/ha applied in treatment no. 1 to 12. 


\section{Effect of PGPR consortium}

PGPR consortium (11/ha) showed the best result to maximum number of fruit/plant (8.40), average fruit weight (609.38 g), yield per plant $(5.14 \mathrm{~kg})$ and yield $(25.73 \mathrm{t} / \mathrm{ha})$ under experimentation. This might be due to with application of PGPR consortium, secretion of ammonia also enhanced in the rhizosphere, which enhance the nutrient uptake potential of plant and improve the fruit yield and yield attributing parameters. PGPR consortium also produces plant growth regulatory substances which stimulate plant growth and yield. Similar finding were also reported Das et al., (2015) and Patel et al., (2018) in bottle gourd, Prasad et al., (2009) and Kumar et al., (2012) in bitter gourd and Anjanappa et al., (2012) in cucumber.

Tables.3 Effect of different organic manures and PGPR consortium on growth parameters of bottle gourd

\begin{tabular}{|c|c|c|c|c|c|c|c|}
\hline Treatment & $\begin{array}{l}\text { Days taken } \\
\text { for } \\
\text { germination }\end{array}$ & $\begin{array}{l}\text { Number of } \\
\text { branches/ } \\
\text { plant } \\
\text { (At the time } \\
\text { of first } \\
\text { picking) }\end{array}$ & $\begin{array}{l}\text { Number of } \\
\text { male } \\
\text { flowers/plant } \\
\text { (At the time of } \\
\text { first picking) }\end{array}$ & $\begin{array}{l}\text { Number of } \\
\text { female } \\
\text { flowers/plant } \\
\text { (At the time } \\
\text { of first } \\
\text { picking) }\end{array}$ & $\begin{array}{c}\text { Sex } \\
\text { ratio } \\
(\text { Female } \\
\text { : Male) }\end{array}$ & $\begin{array}{c}\text { Girth of } \\
\text { fruit }(\mathrm{cm}) \\
(\text { At the } \\
\text { time of } 5^{\text {th }} \\
\text { picking) }\end{array}$ & $\begin{array}{l}\text { Length of } \\
\text { fruit }(\mathrm{cm}) \\
\text { (At the } \\
\text { time of } 5^{\text {th }} \\
\text { picking) }\end{array}$ \\
\hline \multicolumn{8}{|c|}{ Factor A : Organic manures (M) } \\
\hline $\mathbf{M}_{1}$ & 7.65 & 14.38 & 18.86 & 3.16 & 0.168 & 23.85 & 30.93 \\
\hline $\mathbf{M}_{2}$ & 8.46 & 12.30 & 17.34 & 2.72 & 0.155 & 21.16 & 28.32 \\
\hline $\mathbf{M}_{3}$ & 8.10 & 13.72 & 17.86 & 2.95 & 0.163 & 22.57 & 29.75 \\
\hline $\mathbf{M}_{4}$ & 8.77 & 11.71 & 16.89 & 2.54 & 0.149 & 21.03 & 26.42 \\
\hline $\mathbf{M}_{5}$ & 7.85 & 13.97 & 18.16 & 3.02 & 0.164 & 22.87 & 30.01 \\
\hline $\mathbf{M}_{6}$ & 8.51 & 12.01 & 17.05 & 2.66 & 0.154 & 21.11 & 27.54 \\
\hline S.Em. \pm & 0.31 & 0.50 & 0.51 & 0.12 & 0.007 & 0.63 & 0.86 \\
\hline CD at $5 \%$ & NS & 1.45 & NS & 0.34 & NS & 1.83 & 2.51 \\
\hline \multicolumn{8}{|c|}{ Factor B : PGPR consortium (P) } \\
\hline $\mathbf{P}_{1}$ & 8.85 & 12.09 & 17.49 & 2.68 & 0.153 & 21.14 & 27.93 \\
\hline $\mathbf{P}_{2}$ & 7.60 & 13.95 & 17.90 & 3.01 & 0.165 & 23.06 & 29.74 \\
\hline S.Em. \pm & 0.18 & 0.29 & 0.30 & 0.07 & 0.004 & 0.36 & 0.50 \\
\hline CD at $5 \%$ & 0.52 & 0.84 & NS & 0.20 & NS & 1.05 & 1.45 \\
\hline $\begin{array}{c}\text { Interactio } \\
\text { n (MxP) }\end{array}$ & NS & NS & NS & NS & NS & NS & NS \\
\hline \multicolumn{8}{|c|}{ Control vs Rest treatment } \\
\hline Control & 9.65 & 11.12 & 15.55 & 2.02 & 0.131 & 18.31 & 24.88 \\
\hline $\begin{array}{c}\text { Rest } \\
\text { treatment }\end{array}$ & 8.22 & 13.02 & 17.69 & 2.84 & 0.159 & 22.10 & 28.83 \\
\hline S.Em. \pm & 0.32 & 0.52 & 0.53 & 0.12 & 0.007 & 0.65 & 0.90 \\
\hline CD at $5 \%$ & 0.94 & 1.51 & 1.56 & 0.35 & 0.021 & 1.90 & 2.61 \\
\hline CV\% & 9.05 & 9.44 & 7.19 & 10.25 & 11.064 & 7.03 & 7.38 \\
\hline
\end{tabular}


Tables.4 Effect of different organic manures and PGPR consortium on yield and it's attributing parameters of bottle gourd

\begin{tabular}{|c|c|c|c|c|}
\hline Treatment & $\begin{array}{c}\text { Number of } \\
\text { fruits per plant }\end{array}$ & $\begin{array}{l}\text { Average weight } \\
\text { of fruit (g) }\end{array}$ & $\begin{array}{l}\text { Yield per } \\
\text { plant } \\
\text { (kg) }\end{array}$ & $\begin{array}{l}\text { Yield } \\
\text { (t/ha) }\end{array}$ \\
\hline \multicolumn{5}{|c|}{ Factor A : Organic manures (M) } \\
\hline $\mathbf{M}_{1}$ & 8.78 & 637.79 & 5.59 & 27.84 \\
\hline $\mathbf{M}_{2}$ & 7.94 & 566.52 & 4.50 & 22.71 \\
\hline $\mathbf{M}_{3}$ & 8.40 & 607.19 & 5.10 & 25.29 \\
\hline $\mathbf{M}_{4}$ & 7.27 & 546.50 & 3.98 & 20.34 \\
\hline $\mathbf{M}_{5}$ & 8.54 & 618.38 & 5.28 & 26.36 \\
\hline$M_{6}$ & 7.69 & 556.80 & 4.28 & 21.56 \\
\hline S.Em. \pm & 0.27 & 19.25 & 0.18 & 0.92 \\
\hline CD at $5 \%$ & 0.80 & 56.18 & 0.53 & 2.68 \\
\hline \multicolumn{5}{|c|}{ Factor B : PGPR consortium (P) } \\
\hline $\mathbf{P}_{1}$ & 7.81 & 568.36 & 4.44 & 22.30 \\
\hline $\mathbf{P}_{2}$ & 8.40 & 609.38 & 5.14 & 25.73 \\
\hline S.Em. \pm & 0.16 & 11.11 & 0.11 & 0.53 \\
\hline CD at $5 \%$ & 0.46 & 32.44 & 0.31 & 1.55 \\
\hline Interaction (MxP) & NS & NS & NS & NS \\
\hline \multicolumn{5}{|c|}{ Control vs Rest treatment } \\
\hline Control & 6.96 & 510.75 & 3.56 & 19.09 \\
\hline Rest treatment & 8.10 & 588.86 & 4.79 & 24.02 \\
\hline S.Em. \pm & 0.29 & 20.04 & 0.19 & 0.96 \\
\hline CD at $5 \%$ & 0.83 & 58.48 & 0.56 & 2.79 \\
\hline CV\% & 8.40 & 8.09 & 9.55 & 9.51 \\
\hline
\end{tabular}

The results obtained from research experiment, it can be concluded that the application of $100 \%$ RDN from vermicompost $(4.16 \mathrm{t} / \mathrm{ha})$ exhibited the maximum number of branches/plant and number of female flowers/plant at the time of first picking and girth of fruit and length of fruit at the time of $5^{\text {th }}$ picking and also the maximized number of fruits/plant, average weight of fruit, yield per plant and yield per hectare of bottle gourd cv. Anand Bottle Gourd-1.

Application of PGPR consortium (1 l/ha) recorded the minimum days taken for germination and maximum number of branches/plant and number of female flowers/plant at the time of first picking and girth of fruit and length of fruit at the time of $5^{\text {th }}$ picking and also maximized number of fruits/plant, average weight of fruit, yield per plant and yield per hectare of bottle gourd cv. Anand Bottle Gourd-1.

\section{References}

Anjanappa, M., Kumara, B. S., \& Indiresh, K. M. (2012). Growth, yield and quality attributes of cucumber cv. Hassan Local as influenced by integrated nutrient management grown under protected condition. Mysore 
Agriculture Science, 46(1), 32-37.

Anonymous (2016-2017). Indian Horticulture

Database. National Horticulture Board, Ministry of Agriculture, Government of India.

Asha, N. N., Sowmya, P. T., Ranjitha, H. R., \& Balachandra, C. K. (2018). Effect of biofertilizer on growth of ridge gourd. International Journal of Current Microbiology and Applied Sciences, 6, 1422-1426.

Das, R., Mandal, A. R., Priya, A., Das, S. P., \& Kabiraj, J. (2015). Evaluation of integrated nutrient management on the performance of bottle gourd (Lagenaria siceraria (Molina) Standl.). Journal of Applied and Natural Science,7(1), 1825.

Gopalan C, BV. Rama S, Balasubramanian SC. (1982). Nutritive value of Indian food. Indian council of medical research, national institute of nutrition, Hyderabad.

Kloepper, J. W. (2003). A review of mechanisms for plant growth promoting by PGPR. Proceeding of 6th international plant growth promoting rhizobacetria (PGPR) workshop, Calicut, India, 81-90.

Kumar, K. S., Sowmyamala, B. V., Kumar, P. G., Vasudev, P. N., Kumar, R. V., \& Nagaraj, H. T. (2012). Effect of plant growth promoting rhizobacteria (PGPR) on growth and yield of bitter gourd. International Journal of Applied Biology and Pharmaceutical Technology, 3 (1), 1-7.

Nagar, M., Soni, A. K., \& Sarolia, D. K. (2017). Effect of organic manures and different levels of NPK on growth and yield of bottle gourd (Lagenaria siceraria (Mol.) Standl Int. J. Curr. Microbiol. App. Sci, 6 (5), 1776-1780.

Olsen, S. R., Cole, G. V., Watenable, F. S. \&
Dean, L. A. (1954). Estimation of available phosphorus in soil by extraction with sodium bicarbonate. U. S. D. A. Cir. No. 939, pp-19.

Pandey, A., \& Kumar, S. (1989). Potential of Azotobacter and Azospirillum biofertilizer for upland agriculture. J. Scientific Ind. Res. 48, 134-144.

Panse, V. G. and Sukhatme, P. V. (1967). Statistical methods for agricultural workers. Indian Council of Agricultural Research, New Delhi.

Prasad, P. H., Mandal, A. R., Sarkar, A., Thapa, U., \& Maity, T. K. (2009). Effect of biofertilizers and nitrogen on growth and yield attributes of bitter gourd (Momordica charantia L). In Proceedings, International Conference on Horticulture (pp. 738-739).

Patel, D. H., Vadodariya, J. R., Nandre, B. M., \& Pawar, Y. (2018). Studies on organic nutrient management of bottle gourd (Lagenaria siceraria (Mol.) Standl.) under different shadenet condition. International Journal of Chemical Studies, 6 (3), 2722-2726.

Reddy, R., Reddy, M., Reddy, T. Y. N., Reddy, N. S., \& Anjnappa, M. (1998). Effect of organic and inorganic sources of NPK on growth and yield of pea (Pisum sativum). Legume Res., 21 (1), 57-60.

Singh, D. P., Mishra, U. C., Prakash, H. G., \& Mishra, O. (2012). Role of organic farming on yield and economics of bottle gourd after vegetable pea. International Journal of Agricultural Sciences, 8 (1), 165-167.

Thamburaj, S. and Singh, N. (2001). Textbook of Vegetables, Tuber crops and Spices. Published by Directorate of Information and Publication of Agriculture ICAR, New Delhi pp 29-48. 


\section{How to cite this article:}

Nadoda. S. R., A. V. Kotecha, K. S. Vaghela, Aal. J. M. 2020. Effect of Different Organic Manures and PGPR Consortium on Growth and Yield of Bottle Gourd (Lagenaria siceraria Mol. Standl.) CV. Anand Bottle Gourd-1. Int.J.Curr.Microbiol.App.Sci. 9(03): 1467-1474. doi: https://doi.org/10.20546/ijcmas.2020.903.171 